Article

\title{
Information Values on the Consumer's Valuation of non-GM Material: The Case of Cooking Oil in Korea
}

\author{
Kyungsoo Nam, Heesun Lim and Byeong-il Ahn * (B) \\ Department of Food and Resource Economics, Korea University, Seoul 20841, Korea; ksnam@krei.re.kr (K.N.); \\ hslim0831@korea.ac.kr (H.L.) \\ * Correspondence: ahn08@korea.ac.kr
}

Received: 24 August 2020; Accepted: 20 September 2020; Published: 23 September 2020

\begin{abstract}
This paper analyzes the changes in consumer preference that may occur when the current Genetically Modified (GM) crops policy is strengthened by applying mandatory labeling to all processed food that uses GM crops as raw materials. We estimate the change in consumers' willingness to pays for cooking oil before and after providing the information on GM raw material contained in the currently marketed cooking oil to consumers. To this end, a hypothetical cooking oil product using non-GM raw materials is set up, and consumers are classified into high and low awareness groups for genetically modified organisms (GMOs) and those who prefer and do not prefer organic foods. The Contingent Valuation Method (CVM) analyses show the amount of willingness to pay before providing the information for high and low awareness groups for GMOs increases from 23.8 dollars and 18.0 dollars per $1.8 \mathrm{~L}$ to 25.6 dollars and 20.3 dollars, respectively. The value of the information on GM raw materials of a consumer group with high prior knowledge of GMOs is estimated to be 1.8 dollars, and the value of the information of a consumer group with low prior knowledge is estimated to be 2.4 dollars per $1.8 \mathrm{~L}$. The willingness to pay (WTP) change according to the information provision of the group with the highest prior knowledge of GMOs is estimated to be 0.6 dollars, and the WTP change is estimated to be 3.6 dollars for the group with lowest prior knowledge. This implies that the lower the prior knowledge possessed by a consumer, the higher the value of information on GM raw materials elicited.
\end{abstract}

Keywords: genetically modified organism; GMO; contingent valuation method; CVM; perception; preference; value of information; willingness to pay; WTP

\section{Introduction}

Genetically modified (GM) crops contain DNA that is not produced by conventional breeding methods and has low production costs and high productivity [1,2]. For this reason, producers have produced GM crops in many countries, and their production and cultivated area are growing rapidly. However, the safety of GM crops and the intake of GM food is still controversial. Thus, the debate continues over the safety risks and the benefits of producing GM crops [3,4].

As the importance of sustainability emerges, the controversial debate on the use of GM crops is moving towards discussions on food safety and health as well as environmental impacts. The use of GM crops has not only allowed farmers to practice sustainable agricultural production by reducing the use of pesticides and greenhouse gas emissions but also reached the scientific consensus that consuming GM crops is at least as safe as consuming conventional crops [5]. Analyzing environmental impacts associated with using GM crops, Brookes and Barfoot [6] suggest that the use of GM crops had positive environmental impacts by decreasing the use of pesticides and reducing greenhouse gas emissions. DeFrancesco [7] provides evidence that the consumption of GM crops is not harmful to human health and is environmentally safe. In addition, in many studies, GM crop production can 
generate higher profits with higher yields and lower costs $[8,9]$, thereby contributing to the welfare of farmers producing GM crops [10,11]. On the other hand, the claim that producing GM crops has positive effects such as increased yield and reduced costs may not take into account the influences of climate factors in estimating the pure effects on yield and production cost. There are studies showing that the safety of GM foods is also unreliable because the data and analytical methods used in the studies are not reliable [12,13].

Similar debates are taking place in Korea regarding the profitability, safety, and sustainability of genetically modified organisms (GMOs). Some consumers in Korea are responding negatively to the consumption of GM agricultural products and GM foods because the safety of GM foods has not been fully tested. As a result, they argue that the GM food labeling system should be applied to all processed foods which use GM agricultural products as raw materials (Newspaper articles from "Over 90\% of consumers agree with 'Labeling all GMO raw materials'”, Food and Drink Newspaper, 4 October 2018, "Urgent needs to strengthen consumers' rights to know by implementing mandatory full GM food labeling law", newspapers made by consumers, 8 January 2019).In contrast, suppliers and processors of GM products argue that there is no objective evidence that GM foods adversely affect the health of consumers. Therefore, they oppose the complete GM food labeling which could increase costs of food production and its distribution (Newspaper articles from "Concerns of reverse discrimination of domestic companies when introducing mandatory full GM food labeling system", Health News, 19 April 2018, "Why do members of the National Assembly turn their back on mandatory full GM Food labeling system", Consumer Value, 4 February 2019.).

In Korea, GM food labeling standards require that food products should have GM labeling on it if they contain more than $3 \%$ unintentionally mixed GM ingredients. However, some exceptions exempt from being labeled are allowed when genetically modified components are not detected through the heating or compression process (Labeling Standards for Genetically Modified Foods, Article 3-2 of the Food Sanitation Act). Accordingly, even if processed food is made from GM raw materials, there is no obligation to attach GM labeling if GMO components are not detected after going through the processing process. Under the current labeling system in Korea, many consumers are unaware of how much GM raw material is used in the food products since GM food producers are not obligated to label GMOs in the product under the labeling exception if GM components are dissolved during the heating process. In the labeling system for genetically modified foods, targets and standards of the labeling are operated differently depending on the direction of the national agenda on food safety. While there is no labeling system in the US which is the major producing country of GM crops, countries which import a lot of GM foods such as EU countries and Japan operate a mandatory labeling system. Australia, the EU, and China are countries where the labeling system for genetically modified foods has been strengthened compared to Korea, although Australia is the country where the labeling system has been eased. The Australian GMO labeling system, similar to the GMO labeling system of Korea, exempts foods containing new DNA or new proteins from GM labeling if the amount of unintentionally mixed GM ingredients is less than $1 \%$. In the case of the EU and China, the labeling system for genetically modified foods is considerably strengthened as the labeling system for all non-GM foods, regardless of the presence or absence of genetically modified proteins, is not allowed for unintentionally mixed GM ingredients. Japan's GMO labeling system, which is more relaxed than Korea, allows for the exemption of GM labeling if there is less than $5 \%$ of genetically modified ingredients in 8 crops and 33 processed foods such as soybean, corn, potato, canola, cottonseed, alfalfa, sugar beet, and papaya. If the amount of unintentionally mixed GM ingredients is more than $5 \%$, the mandatory GM labeling is applied [14].

For satisfying consumers' right to know, the Korean government considers strengthening the GM labeling policy in such a way that obliges the attachment of GM labels to processed foods if GM crops are used as raw materials, regardless of whether the protein that contains the trace (i.e., DNA) of GM ingredients is left or not. However, strengthening the current policy should consider not only the 
increase in production cost and the change in distribution structure but also the impact of the change in consumer preferences. In this context, this study focuses on consumers' willingness to pay (WTP).

Quite a few previous studies have been conducted on the consumer's willingness to purchase and awareness of GM agricultural products. Hwang et al. [15] analyzed consumer perception of GM agricultural product development and cultivation using a double probit model. The study claims that consumers with more knowledge about GMOs responded positively to the domestic development of GMOs, while those consumers with greater concern about future risks were opposed to domestic farming of GM crops. Korean students were willing to pay a price premium of $54.2 \%$ for non-GM cooking oil and $81.2 \%$ for tofu because the genetically modified protein was not detected in GM cooking oil. Delmond et al. [16] estimated the WTP for bread made from GM raw materials. The results showed that health-sensitive consumers responded negatively to GM food purchases, while price-sensitive consumers showed relatively positive responses to GM food purchases. Consumers who are sensitive to health want to buy relatively fewer GM foods, and those who are sensitive to money want to buy more GM foods. Overall, despite the 5-50\% discount rate, only $20 \%$ of respondents want to buy GM bread. Zhu et al. [17] analyzed the impact of GMO knowledge on WTP by dividing consumers into three groups according to their knowledge level and compared the effects of positive and negative information. As a result, the WTP change due to negative information on GMOs is greater than the one due to positive information. For negative information, the WTP reduction of the consumers with high knowledge is greater than that of consumers with low knowledge. Han [18] analyzed willingness to pay for mandatory GMO labeling for US consumers using the Heckman two-stage estimation model. This analysis showed that consumers prefer mandatory labeling to secure consumers' right to know and choice over GMO safety. Kim et al. [19] compared the willingness to pay for GM food among Korean, Japanese, Norwegian, Taiwanese, and US consumers. Asian countries, except Korea, were less likely to pay additional non-GM premiums, while the United States and Norway were more likely to additionally pay over $50 \%$ for non-GMO food (cooking oil), similar to Korea. Some studies have been conducted on the changes in WTP according to consumer awareness, level of knowledge about GMOs, and types of GMO-related information. However, there is a limited number of studies that focus on the value of information by comparing the results before and after information is given, and no research has been conducted that links the value of information and the economic effect of the changes in consumer preference.

In this study, the changes in consumer preference due to the strengthening GMO labeling policy are examined by estimating the value of information that indicates the use of GM raw materials in the currently marketed cooking oils. For this, we analyze how consumers' willingness to pay changes by presenting information about the GM foods that are not currently labeled but actually use GM materials. Since the consumer's response to the information may vary according to prior knowledge of GM food or interest in food safety, the analysis of this study considers consumer's prior knowledge and safety interests: awareness of GM food and preference for organic food are used as proxy variables for consumer's prior knowledge and food safety interests. For the analysis, a product that uses the GM material is selected and a hypothetical product that uses non-GM ingredients is set up. The degree of change in willingness to pay (hereinafter referred to as WTP) is compared by classifying consumers into groups with high and low awareness of GM foods, and those who prefer organic food and those who do not.

\section{Material and Method}

\subsection{Selection of Subject of Analysis}

In Korea, edible raw materials covered by the GMO labeling system include soybean, corn, canola, and cotton. GM raw materials used in processed foods in Korea, except the ones used for the animal, are soybeans and corns, which are all imported from other countries (soybeans and corns produced domestically are non-GM). Soybeans are mainly used for making cooking oil, and corn is used for 
making starch and starch sugar. Starch and starch sugar are often used as supplementary raw materials rather than as main ingredients of processed foods. Therefore, in general, the amount of starch and starch sugar contained in processed food such as snacks, bread, noodles, etc. is not high, but soybeans are used as the main ingredient of cooking oil (Survey on Raw Material Consumption in Each Food Industry, 2017), thus, its content in cooking oil is relatively very high.

The proportion of import is $99.5 \%$ for corns and $83.3 \%$ for soybeans [20], and $81 \%$ of corns are used for making non-food products (animal feed, etc.). As discussed, when corns are used for food, sugars (starch sugar, etc.) are used as supplementary materials rather than as main ingredients of food (refer to Figure 1). In the case of soybeans, approximately $17 \%$ of domestically produced products are used for making tofu and paste sauce. Imported soybeans which account for $83 \%$ are used for non-foods, $33 \%$ and $39 \%$ are utilized for cooking oil which is the target of the present study and processed products, respectively. In other words, among GM agricultural products that are imported and distributed in Korea, soybean is used as the main raw material for the processed foods consumed by consumers. Among many processed foods that use soybean as the main raw material, cooking oil is chosen to be the subject of this analysis, because soybean content is the highest in making this product. Accordingly, in this study, we investigate the preferences of consumers to non-GM foods, focusing on cooking oil.

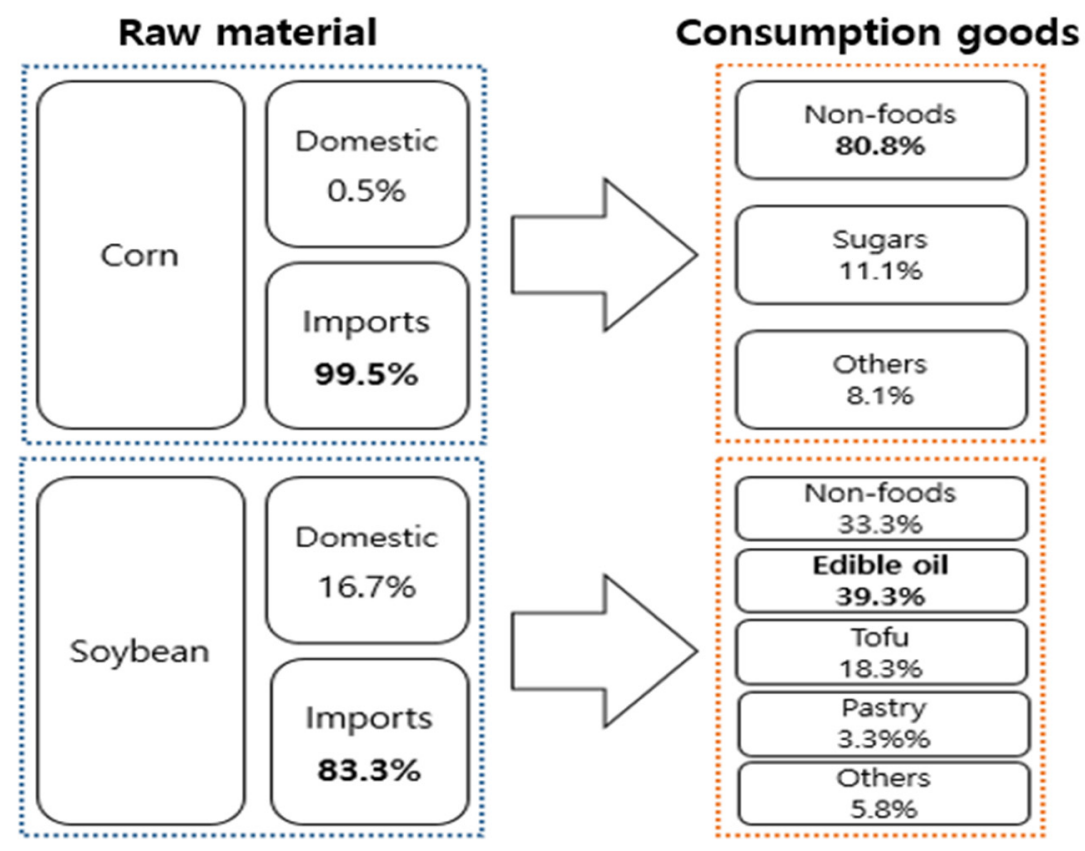

Figure 1. Flowchart of Consumption of Corn and Soybean Raw Materials, Purchase and Inputs are Indicated Based on the Purchase Amount [21].

\subsection{Hypothesis Setting}

Although not labeled under Korea's current GMO labeling system, most cooking oil uses GM raw materials of soybeans. Therefore, we first set up non-GM cooking oil, a virtual commodity, to estimate the WTP of consumers. After providing the information (hereinafter referred to as "GM-use information") that most of the cooking oil available on the market uses GM ingredients, we estimate consumers' WTP again. Through this process, we analyze the difference between WTP before and after providing "GM-use information" and interpret this difference as the value of information (V) as described in Figure 2. The underlying assumption is that consumers prefer non-GM cooking oil to GM cooking oil. This assumption can be tested by the change in WTP after providing "GM-use information" on cooking oil. If the WTP for non-GM cooking oil increases after the "GM-use information" is provided, it can be interpreted that consumers prefer non-GM cooking oil to GM cooking oil. 


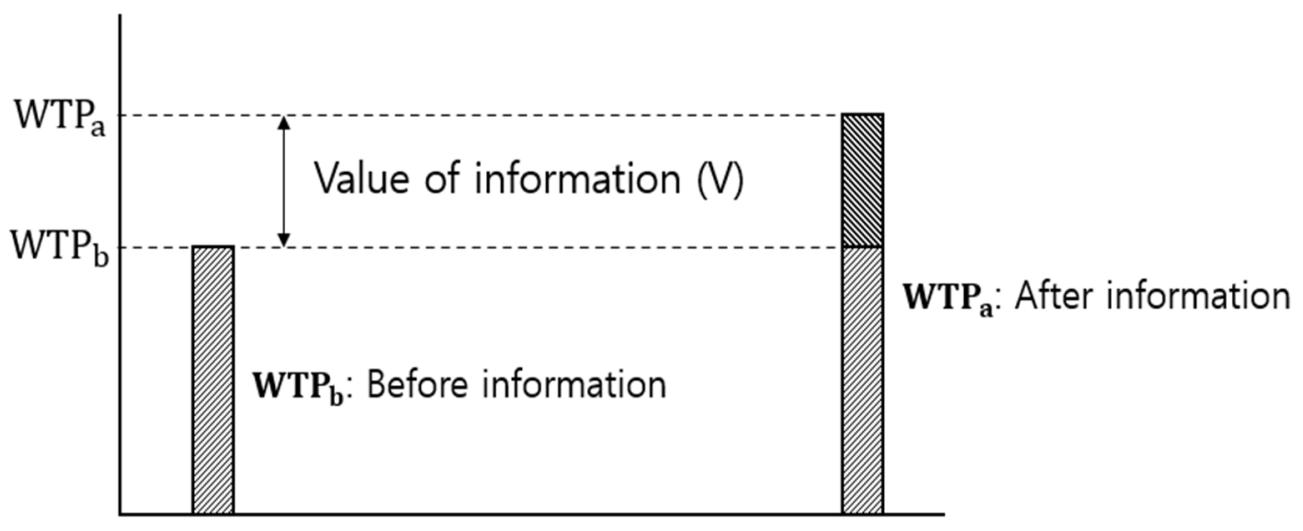

Figure 2. The Value of Information on Non-Genetically Modified Cooking Oil; WTP—willingness to pay.

For the empirical estimations, we set the following four hypotheses.

Hypothesis 1 (H1). WTP for non-GM foods increases after providing "GM-use information" to consumers with high as well as low prior knowledge about GMOs.

Hypothesis 2 (H2). The change in WTP by providing "GM-use information" will be greater in consumers with low prior knowledge than in consumers with high prior knowledge (awareness) about GMOs.

Hypothesis 3 (H3). Consumers with low prior knowledge about GMOs do not have higher WTP for non-GM foods compared to the WTP for non-GM foods from the consumers with high prior knowledge about GMOs, after both consumer groups are provided "GM-use information".

These hypotheses can be viewed in Figure 3, where the WTP of the consumers with high prior knowledge before providing GM-use information is expressed as $\mathrm{WTP}_{\mathrm{bH}}$, these consumers' WTP after GM-use information provision is expressed as $\mathrm{WTP}_{\mathrm{aH}}$. WTP of the consumers with low prior knowledge before providing GM-use information is expressed as $\mathrm{WTP}_{\mathrm{bL}}$ while WTP of these consumers after GM-use information provision is expressed as $\mathrm{WTP}_{\mathrm{aL}}$. In addition, the WTP change due to GM-use information provision from consumers with high prior knowledge is expressed as $\mathrm{V}_{\mathrm{H}}$, and the WTP change due to GM-use information provision from consumers with low prior knowledge is expressed as $\mathrm{V}_{\mathrm{L}}$.

Hypothesis 1 is a case where even consumers who think they know more than a certain level about GMOs may not know that most of the cooking oil available on the market is made of GM raw materials. Therefore, unless consumers with high prior knowledge are very well aware of the use of GM raw materials for the current cooking oil on the market, the provision of GM-use information is expected to lead to a rise in WTP for non-GM cooking oils $\left(\mathrm{V}_{\mathrm{H}}>0\right)$.

In the case of Hypothesis 2, if the value of GM-use information is changed by the consumer's prior knowledge, it will be greater in the lower group than in the higher knowledge group, as shown in cases 1,2 , and 3 of Figure $3\left(V_{L} \geq V_{H}\right)$. In other words, the average change in WTP will be small in the higher awareness group because consumers with higher prior knowledge are more likely to be aware of the use of GM raw materials for the current cooking oil than consumers with low prior knowledge about GMOs.

Hypothesis 3 is a case where even if GM-use information is provided, the difference in WTP for non-GM cooking across two groups still exists due to the differences in consumers' dispositions, such as sensitivity to safe food. That is, after GM-use information is provided, if the value of the information offset the difference completely like case 1, the WTPs for non-GM cooking oil from the two groups will be the same $\left(\mathrm{WTP}_{\mathrm{aL}}=\mathrm{WTP}_{\mathrm{aH}}\right)$. However, this is would be the very rare case. Reality is 
likely to be the case 2 or case 3 . In other words, groups with low prior knowledge are more likely to include consumers who don't have a strong preference for the use of non-GM materials and do not discriminate significantly between non-GM and GM materials. Therefore, the value of GM-use information does not completely offset the difference in WTP due to prior knowledge. That is why, even if the value of GM-use information for a group with low prior knowledge is bigger than that of the group with high prior knowledge, the WTP for non-GM food for a group with high prior knowledge is still likely to be high after the provision of GM-use information $\left(\mathrm{WTP}_{\mathrm{aL}} \leq \mathrm{WTP}_{\mathrm{aH}}\right)$.

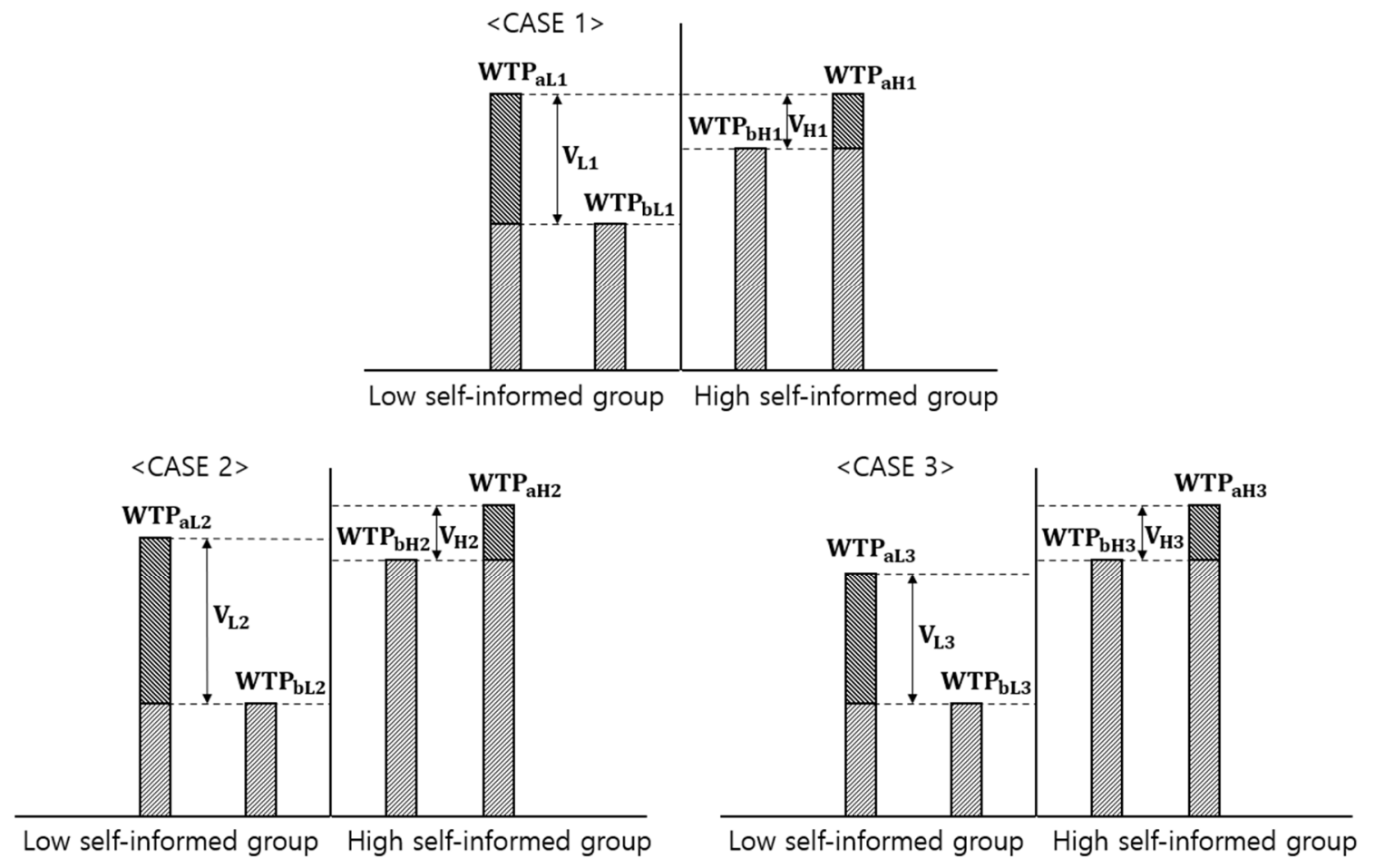

Figure 3. Value of Information based on Consumer's Prior Knowledge.

Through these discussions, we can say that if $\mathrm{V}_{\mathrm{L}}$ is large enough like case 2, the WTP after providing GM-use information from a consumer group with low prior knowledge will be bigger than the WTP before providing GM-use information from a group with high prior knowledge $\left(\mathrm{WTP}_{\mathrm{aL}}>\mathrm{WTP}_{\mathrm{bH}}\right)$. On the other hand, if $\mathrm{V}_{\mathrm{L}}$ is not big enough like case 3, the WTP of a consumer group with low prior knowledge after the provision of GM-use information will be smaller than the WTP of a group with high prior knowledge before providing GM-use information (WTP_aL $<$ WTP_bH). Through empirical analysis, the WTP difference (value of information) can be estimated before and after providing the information on GM raw materials. In addition, we can also test how the value of the information offsets the difference in WTP of consumers with high and low prior knowledge before the provision of the information.

\subsection{Empirical Model: CVM}

The valuation of a virtual non-GM food commodity can be performed using the contingent valuation method (CVM), which is a commonly used tool for valuating non-market goods. The CVM analysis method used in this study adopts the methodology stated in Lopez-Feldman [22]. In the case of replacing the raw material of cooking oil currently produced by using GM raw material $\left(Z^{0}\right)$ with non-GM raw material $\left(Z^{1}\right)$, the indirect utility function of individual consumer $i$ can be expressed as Equation (1).

$$
V_{i}\left(P, y_{i}-H_{i}, Z^{1}\right)=V_{i}\left(P, y_{i}, Z^{0}\right)
$$


where $P$ is the price vector of market goods of interest and $y_{i}$ is the income level of the individual consumer $i . H_{i}$ represents the level of income that should be reduced to offset the increase in utility from consuming non-GM product so that $i$ can maintain the same level of utility when replacing raw materials of cooking oil from GM to non-GM. In other words, $H_{i}$ means consumer's WTP when replacing raw materials of cooking oil from GM to non-GM. If the consumer's WTP can change when objective GM-use information is given and the extent depends on the prior knowledge of GM food as well as the concern for food safety which is represented by the preference for the organic food, Equation (1) can be rewritten as Equation (2).

$$
\begin{array}{r}
V_{i}\left[P, y_{i}-\left(H_{i}(\rho, \psi)+\theta D_{1}\right), Z^{1}\right]=V_{i}\left[P, y_{i}, Z^{0}\right] \\
D_{1}=\left\{\begin{array}{c}
0: \text { Before providing objective information } \\
1: \text { After providing objective information }
\end{array}\right. \\
H_{i}(\rho, \psi)=\left\{\begin{array}{c}
H_{i}(\rho, \psi \mid \rho=1, \bar{\psi}) \\
H_{i}(\rho, \psi \mid \rho=0, \bar{\psi}) \\
H_{i}(\psi, \rho \mid \psi=1, \bar{\rho}) \\
H_{i}(\psi, \rho \mid \psi=0, \bar{\rho})
\end{array}\right.
\end{array}
$$

where $\rho$ is the prior knowledge of GM foods ( $\bar{\rho}$ : average awareness), $\psi$ is the preference for organic foods ( $\bar{\psi}$ : average awareness), $D_{1}$ is dummy variable that represents the status regarding before and after providing GM-use information that indicates currently marketed cooking oil is made with GM raw materials, and $\theta$ is the degree of WTP change depending on GM-use information. In this study, the WTP for non-GM cooking oil is estimated using the dichotomous choice method recommended by the US National Oceanographic and Atmospheric Administration (NOAA) panel. The dichotomous choice approach offers a certain amount for virtual goods and requests a yes or no answer from the respondents.

In the case of the dichotomous choice, the WTP of the individual economic entity $i$ for non-market goods can be set as the linear function of the characteristic vector $z_{i}$ of $i$ and $u_{i}$ which is an error term as shown in Equation (3).

$$
\operatorname{WTP}_{i}\left(z_{i}, u_{i}\right)=z_{i} \beta+u
$$

where $\beta$ is the parameter vector representing the linear combination of $z_{i}$, the explanatory variable $\left(z_{i}\right)$ includes respondent's characteristic variables, household characteristics, awareness of GM food, and preferences for organic food. If the price $\left(t_{i}\right)$ presented in the survey is smaller than consumer's own $W T P_{i}$, the consumer's answer is yes $\left(y_{i}=1\right)$. In the case where the characteristic vector $z_{i}$ is given, the probability of responding yes can be expressed as in Equation (3). Assuming a normal distribution of the error term $\left(u_{t}\right)$ in Equation (4), we can standardize Equation (4) and represent it as a cumulative distribution function as shown in Equation (5).

$$
\begin{gathered}
\operatorname{Pr}\left(y_{i}=1 \mid z_{i}\right)=\operatorname{Pr}\left(W T P_{i}>t_{i}\right)=\operatorname{Pr}\left(z_{i} \beta+u_{i}>t_{i}\right)=\operatorname{Pr}\left(u_{i}>t_{i}-z_{i} \beta\right) \\
\text { if } u_{i} \sim \text { i.i.d.N }\left(0, \sigma^{2}\right) \quad v_{i}=u_{i} / \sigma \sim \text { i.i.d. } N(0,1) \\
\operatorname{Pr}\left(y_{i}=1 \mid z_{i}\right)=\operatorname{Pr}\left(v_{i}>\frac{t_{i}-z_{i}^{\prime} \beta}{\sigma}\right) \\
=1-\Phi\left(\frac{t_{i}-z_{i}^{\prime} \beta}{\sigma}\right) \\
=\Phi\left(z_{i}^{\prime} \frac{\beta}{\sigma}-t_{i} \frac{1}{\sigma}\right) \\
=\Phi\left(z_{i}^{\prime} \alpha-t_{i} \delta\right)
\end{gathered}
$$


The answer to the single-bounded dichotomous choice (hereinafter referred to as SBDC) is yes or no, which fits a binomial selection model. In this study, we assume a standard normal distribution and estimate the empirical results based on a probit model. In the probit model, the estimated coefficient for the vector of respondent's characteristic $\hat{\alpha}(=\beta / \sigma)$ and the estimated coefficient for the amount presented $\hat{\delta}(=1 / \sigma)$ can be obtained and $\hat{\beta}(=-\hat{\alpha} / \hat{\delta})$ can be calculated using the two coefficients. The use of only part of the respondent's response to the suggested price (yes or no) has the disadvantage of low efficiency and wider confidence intervals for the estimated WTP. To solve this problem, we can either increase the number of samples significantly or choose a double-bounded dichotomous choice (hereinafter referred to as DBDC) questioning method that repeats bi-choice questions [23,24]. The present study adopts the DBDC question method among the two alternatives.

The DBDC question method is a method of repeating the dichotomy question by first presenting the price $t^{1}$ and then presenting an amount greater than $t^{1}$ if the respondent selects yes and presenting an amount less than $t^{1}$ if the respondent selects no. Consumers' responses from the DBDC question take four forms: (yes, no), (yes, yes), (no, yes), and (no, no), and the corresponding WTP in each case can be written as $t^{1} \leq W T P \leq t^{2}, t^{2} \leq W T P \leq \infty, t^{2} \leq W T P<t^{1}$ and $0<W T P<t^{2}$, respectively. In this case, the log likelihood function constructed using these four probabilities is expressed by the following Equation (6).

$$
\begin{aligned}
& \ln L=\sum_{i=1}^{N}\left[d_{i}^{y n} \ln \left(\Phi\left(z_{i}^{\prime} \frac{\beta}{\sigma}-\frac{t^{1}}{\sigma}\right)-\Phi\left(z_{i}^{\prime} \frac{\beta}{\sigma}-\frac{t^{2}}{\sigma}\right)\right)+d_{i}^{y y} \ln \left(\Phi\left(z_{i}^{\prime} \frac{\beta}{\sigma}-\frac{t^{2}}{\sigma}\right)\right)\right. \\
& \left.+d_{i}^{n y} \ln \left(\Phi\left(z_{i}^{\prime} \frac{\beta}{\sigma}-\frac{t^{2}}{\sigma}\right)-d_{i}^{y n} \ln \Phi\left(z_{i}^{\prime} \frac{\beta}{\sigma}-\frac{t^{1}}{\sigma}\right)\right)+d_{i}^{n n} \ln \left(1-\Phi\left(z_{i}^{\prime} \frac{\beta}{\sigma}-\frac{t^{2}}{\sigma}\right)\right)\right]
\end{aligned}
$$

where $d_{i}^{y n}, d_{i}^{y y}, d_{i}^{n y}$, and $d_{i}^{n n}$ have a value of 1 for (yes, no), (yes, yes), (no, yes), and (no, no), respectively, and a value of 0 for other cases. There are two methods for estimating the DBDC question method. First, the WTP is calculated by estimating each of the four probabilities using Equation (3). Second, the WTP is calculated by maximum likelihood estimation (MLE) method using the log likelihood function of Equation (4). Using both methods, the same value is calculated. For the MLE method, $\hat{\beta}$ and $\hat{\sigma}$ are estimated directly rather than estimating $\hat{\alpha}$ and $\hat{\delta}$ to calculate $\hat{\beta}$.

\subsection{Data}

For this study, the Cognitive Consulting Group, a specialized survey company, conducted a survey of 250 consumers for about 20 days from 3 to 21 September 2018. Proportions were allocated for gender, age, and residence in designing the sample. Survey questionnaires were sent via email to consumers who were willing to participate. We used the computer-assisted web interview (CAWI) method, in which a consumer visits a survey participation site on the Internet and joins the survey (refer to Tables A1 and A2).

According to the demographic characteristics of the survey respondents in Table 1, men and women each make up 50\% of the sample, with 168 married $(67.2 \%)$ and 82 single (32.8\%). In terms of residence area, the most of respondents are residents of Seoul, Gyeonggi, and Incheon area (119 people, $47.6 \%$ ). The monthly average household income is high in the group of 3.568 to 5.352 dollars with 78 respondents (31.2\%), and 1.784 to 3.568 dollars with 77 respondents $(30.8 \%)$. For occupation, employees are the highest with 114 respondents (45.6\%). Age is estimated at around $20 \%$ for different age groups. The unit of the survey data and analysis result is the US dollar, and the average exchange rate (1.121 won/US dollar) in August 2018 is applied. Regarding the awareness of GM food and preference for organic food, $79.2 \%$ of the respondents respond that they have either "heard of" or have "some knowledge" of GM food and $85.2 \%$ of the respondents respond that they are either "neutral" or "prefer" organic food. 
Table 1. Socioeconomic Characteristics of the Respondents.

\begin{tabular}{|c|c|c|c|c|c|c|c|}
\hline \multicolumn{2}{|c|}{ Classification } & \multirow{2}{*}{$\begin{array}{c}\text { No. of Respondents } \\
125\end{array}$} & \multirow{2}{*}{$\begin{array}{c}\text { Ratio (\%) } \\
50.0\end{array}$} & \multicolumn{2}{|c|}{ Classification } & \multirow{2}{*}{$\begin{array}{c}\text { No. of Respondents } \\
48\end{array}$} & \multirow{2}{*}{$\begin{array}{c}\text { Ratio (\% } \\
19.2\end{array}$} \\
\hline C & Male & & & \multirow{5}{*}{ Age } & $20-29$ & & \\
\hline Gender & Female & 125 & 50.0 & & $30-39$ & 45 & 18.0 \\
\hline \multirow{2}{*}{ Marriage } & No & 82 & 32.8 & & $40-49$ & 56 & 22.4 \\
\hline & Yes & 168 & 67.2 & & $50-59$ & 56 & 22.4 \\
\hline \multirow{3}{*}{ Education } & Under high school & 62 & 24.8 & & over 60 & 45 & 18.0 \\
\hline & University & 152 & 60.8 & \multirow{7}{*}{ Occupation } & Student & 16 & 6.4 \\
\hline & Graduate and above & 36 & 14.4 & & Housewife & 43 & 17.2 \\
\hline \multirow{6}{*}{$\begin{array}{l}\text { Monthly household income } \\
\text { (US dollars) }\end{array}$} & Below 1.784 & 13 & 5.2 & & Employee & 114 & 45.6 \\
\hline & 1.784 to 3.568 & 77 & 30.8 & & Professor and researcher & 8 & 3.2 \\
\hline & 3.568 to 5.352 & 78 & 31.2 & & Government official & 19 & 7.6 \\
\hline & 5.352 to 7137 & 38 & 15.2 & & Self-employed & 31 & 12.4 \\
\hline & 7.137 to 8.921 & 21 & 8.4 & & Others & 19 & 7.6 \\
\hline & Over 8921 & 23 & 9.2 & \multirow{6}{*}{ Residential areas } & Seoul/Gyeonggi/Incheon & 119 & 47.6 \\
\hline \multirow{5}{*}{$\begin{array}{l}\text { Monthly household food } \\
\text { consumption expenditure }\end{array}$} & Below 446 & 33 & 13.2 & & Busan/Gyeongnam & 32 & 12.8 \\
\hline & 446 to 892 & 69 & 27.6 & & Ulsan/Daegu/Gyeongbuk & 32 & 12.8 \\
\hline & 892 to 1338 & 65 & 26 & & Gwangju/Jeolla & 24 & 9.6 \\
\hline & 1.338 to 1.784 & 34 & 13.6 & & Daejeon/Chungcheong/Sejong & 27 & 10.8 \\
\hline & Over 1.784 & 49 & 19.6 & & Gangwon/Jeju & 16 & 6.4 \\
\hline \multirow{2}{*}{ Having disease } & Yes & 104 & 41.6 & \multirow{2}{*}{$\begin{array}{l}\text { Having children } \\
\text { under } 8\end{array}$} & Yes & 37 & 14.8 \\
\hline & No & 146 & 58.4 & & No & 213 & 85.2 \\
\hline \multirow{4}{*}{ Awareness of GMO } & Never heard & 31 & 12.4 & \multirow{5}{*}{$\begin{array}{l}\text { Preference for } \\
\text { organic food }\end{array}$} & Strongly do not prefer & 3 & 1.2 \\
\hline & Heard of it & 83 & 33.2 & & Do not prefer & 11 & 4.4 \\
\hline & Knows little & 115 & 46.0 & & Neutral & 92 & 36.8 \\
\hline & Knows well & 21 & 8.4 & & Prefer & 121 & 48.4 \\
\hline Total & & $250(100)$ & & & Strongly prefer & 23 & 9.2 \\
\hline
\end{tabular}


The responses of the DBDC questionnaire were utilized to estimate the willingness to pay for the virtual non-GM cooking oil. The base price suggested in the first question is composed of four stages (8.9 dollars, 17.8 dollars, 26.8 dollars, 35.7 dollars) considering the price of $1.8 \mathrm{~L}$ (the most common size marketed currently) of cooking oil made with GM raw materials. If the response to the first question turned out to be positive, the second price was presented twice as high, and if the answer was negative, half of the price was presented. To analyze consumer responses to the objective information, we conducted a survey before providing GM-use information that most of the current cooking oils in the market are made with GM raw materials and the same survey was conducted again after providing the GM-use information to the same respondent.

According to the response of the first question (SBDC), the higher the price for the hypothetical cooking oil using non-GM raw material, the lower number of consumers who are willing to buy was revealed (refer to Figure 4). The same result of a negative correlation between the suggested price and revealed number of consumers who were willing to buy was found from the estimations based on the survey after providing GM-use information. The provision of GM-use information turned out to influence the number of consumers who were willing to buy. Before providing the information, $76.6 \%$ of consumers were willing to purchase the cooking oil that is made of non-GM soybean at the price of 8.9 dollars $/ 1.8 \mathrm{~L}$. However, $80 \%$ of consumers answered to purchase non-GM cooking oil at 8.9 dollars after providing the information. For the suggested price of 17.8 dollars, $49.1 \%$ of consumers were willing to purchase before providing the information and $54.5 \%$ of consumers answered to purchase the product after providing the information. Moreover, consumers who were willing to purchase at 26.8 and 35.7 dollars before providing the information increased from $31.5 \%$ and $29 \%$ to $38.4 \%$ and $32.3 \%$, respectively, after the provision of the information. The responses to the DBDC are similar to those of the SBDC (refer to Table A3).

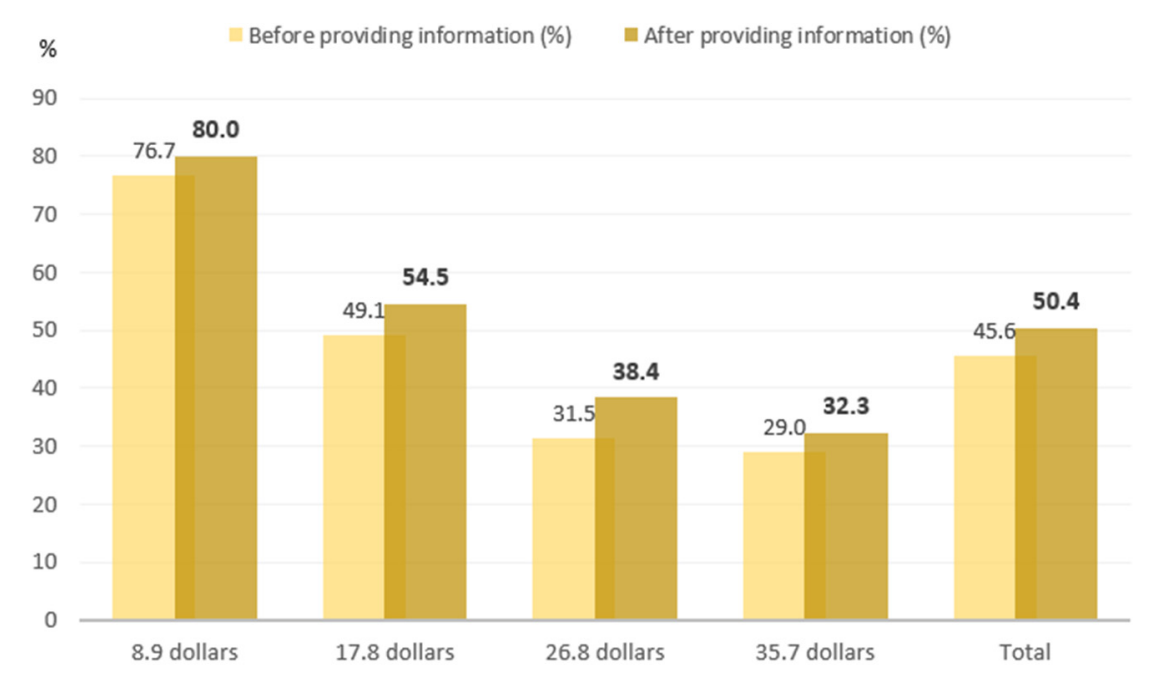

Figure 4. Positive Response Rate by Amount Presented Before and After Information is Provided (Single-Bounded Dichotomous Choice (SBDC)).

\section{Estimation Results}

\subsection{Results from $S B D C$}

Before estimating the DBDC using the maximum likelihood estimation (MLE) method, the SBDC CVM was estimated utilizing the probit model. Through this process, significant variables affecting willingness to pay for non-GM cooking oil were selected, and the WTP was estimated through the selected variables. Finally, the result of change in WTP before and after providing GM-use information was estimated and compared. The estimation process was repeated, eliminating insignificant variables, to select demographic variables that are going to be included in the analysis. Based on these screening 
processes, the final estimation of the SBDC (and the DBDC as shown in the next section) CVM included price, having disease, average monthly food expenditure, organic food preference, and GMO awareness (refer to Table A4).

The estimated results of the probit model including the presented price and selected variables are reported in Table 2. As a result of the probit model analysis that includes demographic characteristics, it is estimated that the value $(\hat{\delta})$ for the presented price $(1 / \sigma)$ is negative before and after providing GM-use information and is statistically significant at a $1 \%$ significance level. Before providing GM-use information, all variables except for the constant are estimated to be significant. After providing the information, all variables except for the constant and the monthly average food consumption expenditure variable are estimated to be significant. The estimated results show that there is a high probability of purchasing non-GM food for a group with a disease compare to those without disease, a group with larger monthly average food consumption expenditure, a group with high GMO awareness compared to those with low, and a group who prefer organic food to those who do not prefer.

Table 2. Estimate Results of WTP using SBDC: WTP for Non-Genetically Modified Cooking Oil.

\begin{tabular}{|c|c|c|c|c|}
\hline \multirow{2}{*}{ Variables } & \multicolumn{2}{|c|}{ Before Providing Information } & \multicolumn{2}{|c|}{ After Providing Information } \\
\hline & Coefficients & t-Value & Coefficients & t-Value \\
\hline Amount presented & $-0.473^{-4 * * *}$ & -5.79 & $-0.459^{-4 * * *}$ & -5.68 \\
\hline Having disease & $0.368 * *$ & 2.08 & $0.368 * *$ & 2.10 \\
\hline $\begin{array}{l}\text { Monthly food consumption } \\
\text { expenditure }\end{array}$ & $0.001 *$ & 1.73 & 0.001 & 1.03 \\
\hline Preferences for organic food & $0.507 * * *$ & 2.74 & $0.595^{* * *}$ & 3.25 \\
\hline Awareness of GMO & $0.430 * *$ & 2.32 & $0.329 *$ & 1.79 \\
\hline Constant & 0.221 & 0.85 & 0.415 & 1.59 \\
\hline Pseudo $\mathrm{R}^{2}$ & \multicolumn{2}{|c|}{0.184} & \multicolumn{2}{|c|}{0.175} \\
\hline Log likelihood & \multicolumn{2}{|c|}{$-140,580$} & \multicolumn{2}{|c|}{$-143,031$} \\
\hline$\chi^{2}(5)$ & \multicolumn{2}{|c|}{63,470} & \multicolumn{2}{|c|}{60,490} \\
\hline prob $>\chi^{2}$ & \multicolumn{2}{|c|}{0.000} & \multicolumn{2}{|c|}{0.000} \\
\hline Average WTP ${ }^{1}$ & $20.3^{* * *}$ & 12.11 & $23.1^{* * *}$ & 13.87 \\
\hline
\end{tabular}

Note: ${ }^{* * *}, * *$ and $*$ denote significant at $1 \%, 5 \%$, and $10 \%$, respectively. ${ }^{1}$ Variables other than the amount presented are the results of the WTP estimation when having the average value.

The willingness to pay for non-GM cooking oil for $1.8 \mathrm{~L}$ is calculated through $\hat{\beta}=-\hat{\alpha} / \hat{\delta}$ equation by applying the estimated coefficient value to Equation (5). Using the average value of all explanatory variables except for the presented price (having disease, average monthly food consumption expenditure, preference on organic food, and GMO awareness), the consumer's willingness to pay for non-GM cooking oil is estimated to be 20.3 dollars before providing the information on GM raw materials and 23.1 dollars after providing the information. As a result, by providing GM-use information, the amount of WTP increases by 2.8 dollars on average compared to the amount before the information is provided. The result of this analysis confirms the assumption that consumers prefer non-GM foods to GM foods.

\subsection{Results from $D B D C$}

As described earlier, the SBDC is low in efficiency and has a large confidence interval for the estimated WTP because it uses only the response to the suggested price, which is a part of the respondents' information. Therefore, to solve this problem, the WTP of the non-GM cooking oil was reestimated using the DBDC. The results of the DBDC questionnaire were estimated by MLE using the log-likelihood function of Equation (4) and the results were compared in the setting before and after 
providing GM-use information. In addition, the case of applying the awareness variable for GMOs as a dummy variable and the case of applying it as a continuous variable are presented in Table 3. As reported, the average monthly food expenditure, organic food preference, and GMO awareness variables are estimated to be significant under all conditions. In the case of disease, it is analyzed to be significant when awareness of GMO is applied as a dummy variable and before GM-use information is provided.

Table 3. Estimate Results of WTP using Double-Bounded Dichotomous Choice (DBDC) Maximum Likelihood Estimation (MLE): WTP for Non-GM Cooking Oil.

\begin{tabular}{|c|c|c|c|c|c|}
\hline \multirow{2}{*}{\multicolumn{2}{|c|}{ Variables }} & \multicolumn{2}{|c|}{ Awareness of GMO: Dummy Variable } & \multicolumn{2}{|c|}{ Awareness of GMO: Continuous Variable } \\
\hline & & $\begin{array}{l}\text { Before Providing } \\
\text { Information }\end{array}$ & $\begin{array}{l}\text { After Providing } \\
\text { Information }\end{array}$ & $\begin{array}{l}\text { Before Providing } \\
\text { Information }\end{array}$ & $\begin{array}{l}\text { After Providing } \\
\text { Information }\end{array}$ \\
\hline \multirow{4}{*}{$\hat{\beta}$} & Having disease & $\begin{array}{c}3.8^{*} \\
(1.71)\end{array}$ & $\begin{array}{c}3.4 \\
(1.54)\end{array}$ & $\begin{array}{c}3.3 \\
(1.50)\end{array}$ & $\begin{array}{c}3.0 \\
(1.39)\end{array}$ \\
\hline & $\begin{array}{l}\text { Monthly food } \\
\text { consumption } \\
\text { expenditure }\end{array}$ & $\begin{array}{l}0.03^{* * *} \\
(3.36)\end{array}$ & $\begin{array}{l}0.03^{* * *} \\
(2.73)\end{array}$ & $\begin{array}{l}0.03^{* * *} \\
(3.28)\end{array}$ & $\begin{array}{l}0.03^{* * *} \\
(2.68)\end{array}$ \\
\hline & $\begin{array}{l}\text { Preference for } \\
\text { organic food }\end{array}$ & $\begin{array}{l}6.6^{* *} \\
(2.83)\end{array}$ & $\begin{array}{l}6.9^{* * *} \\
(2.97)\end{array}$ & $\begin{array}{l}6.3 * * * \\
(2.68)\end{array}$ & $\begin{array}{l}6.8^{* * *} \\
(2.93)\end{array}$ \\
\hline & $\begin{array}{c}\text { Awareness of } \\
\text { GMO }\end{array}$ & $\begin{array}{l}5.8^{* *} \\
(2.52)\end{array}$ & $\begin{array}{l}5.2^{* *} \\
(2.30)\end{array}$ & $\begin{array}{l}4.1^{* * * *} \\
(2.87)\end{array}$ & $\begin{array}{l}3.2^{* *} \\
(2.23)\end{array}$ \\
\hline & Constant & $\begin{array}{l}8.3^{* * *} \\
(3.53)\end{array}$ & $\begin{array}{l}11.6^{* * *} \\
(5.09)\end{array}$ & $\begin{array}{c}1.6 \\
(0.43)\end{array}$ & $\begin{array}{l}6.7^{*} \\
(1.87)\end{array}$ \\
\hline & $\hat{\sigma}$ & $\begin{array}{l}15.6^{* * *} \\
(15.73)\end{array}$ & $\begin{array}{l}15.4^{* * *} \\
(16.09)\end{array}$ & $\begin{array}{l}15.5^{* * *} \\
(15.74)\end{array}$ & $\begin{array}{l}15.4^{* * *} \\
(16.10)\end{array}$ \\
\hline & og likelihood & -320.81 & -322.07 & -319.87 & -322.21 \\
\hline & $\chi^{2}(4)$ & 38.65 & 33.98 & 40.36 & 33.71 \\
\hline & prob $>\chi^{2}$ & 0.00 & 0.00 & 0.00 & 0.00 \\
\hline & rerage WTP ${ }^{(1)}$ & $\begin{array}{l}21.1^{* * *} \\
(19.49)\end{array}$ & $\begin{array}{l}23.2^{* * *} \\
(21.67)\end{array}$ & - & - \\
\hline
\end{tabular}

Note: $t$-values are in parentheses, and ${ }^{* * *}, * *$, and ${ }^{*}$ denote significant at $1 \%, 5 \%$, and $10 \%$, respectively. ${ }^{(1)}$ Variables other than the amount presented are the results of the WTP estimation when having the average value.

Organic food preference, a proxy variable for food safety interests, was divided into a preferred group and a non-preferred group, and the recognition of GMO, a proxy variable for prior knowledge about GMOs, was divided into a high recognition group and a low group. As a result of estimating the awareness of GMOs as a dummy variable, the group preferring organic food shows that additional WTP for non-GM cooking oil (1.8 L standard) is 6.6 dollars before providing GM-use information and 6.9 dollars after providing the information, compared to that of the non-preferred group. The additional WTP of a group with higher awareness of GMOs compared to that of a group with lower is found to be 5.8 dollars before providing the information and 5.2 dollars after providing the information. When comparing the before and after providing GM-use information, the WTP increases due to the preference for organic foods, while the WTP decreases due to awareness of GMOs. This can be interpreted as an increase in the amount of willingness to pay after consumers with low awareness of GMOs have acquired the information. As a result of estimating the awareness of GMOs as a continuous variable (four stages), the additional WTP of organic food preference group is 6.3 dollars before providing GM-use information and 6.8 dollars after providing the information, compared to that of the non-preferred group. If the awareness of the GMOs is increased by one level, the WTP will increase by 4.1 dollars before providing the information and 3.2 dollars after providing the information, based on the estimation results.

As described before, the estimation result through MLE can directly identify rather than calculating an estimate $(\hat{\beta})$ for the WTP. However, when adding demographic variables as well as the presented 
prices as explanatory variables, the sum of each estimate to a specific condition becomes the amount of willingness to pay. WTP can be obtained from the sum of the estimated coefficients when the values of demographic variables are average, or in certain groups (such as men or women) or under certain conditions (such as those with or without disease). In deriving WTP, we applied the average of having a disease and monthly average food consumption expenditure for the respondents. We compared derived consumers' WTP according to organic food preference and GMO awareness, and analyzed WTP change when GM-use information is provided under each condition. Using the estimation results in Table 3, the consumer's WTP for non-GM cooking oil was calculated when all explanatory variables are at the level of average. The WTP for non-GM cooking oil is estimated to be 21.1 dollars before providing the information on the use of GM material. After the provision of the information, the WTP for non-GM cooking oil rises to 23.2 dollars. Based on these results, the value of GM-use information is estimated to be 2.1 dollars. These results indicate that consumers are willing to pay $\$ 2.1$ more on average for non-GM cooking oils. In other words, the provision of the information can be seen to increase the demand for non-GM cooking oil by about $10 \%$, and, accordingly, if the price of non-GM cooking oil remains at the current level, the provision of information will increase consumer surplus.

\subsection{The WTP Based on GMO Awareness}

Consumers were divided into two groups according to GMO awareness for examining the effect of providing GM-use information according to the prior knowledge on GMOs. As a result, the WTP for the group with high GMO awareness increases from 23.8 dollars to 25.6 dollars after the information is provided and the WTP for the group with low GMO awareness increases from 18.0 dollars to 20.3 dollars after the information provision. Therefore, the change in WTP for the group with high GMO awareness is 1.8 dollars (7.6\%) and the change in WTP for the group with low GMO awareness is 2.3 dollars (13.4\%). This implies that the value of GM-use information is estimated to be bigger in the group with less prior knowledge of GMOs. This result suggests that hypothesis 1 and hypothesis 2 can be accepted. However, it is found to be less than the level to offset the WTP before providing the information as shown in case 3 of Figure 3, which implies we can accept hypothesis 3. In addition, it is analyzed that the WTP (23.8 dollars) of the group with high prior knowledge before providing the information is bigger than the WTP (20.3 dollars) of the group with low prior knowledge after providing the information. Therefore, it can be interpreted that case 3 in Figure 3 would be the case.

Organic food preference is selected as a variable for food safety concerns, and the results are also presented for the comparison. As a result, the WTP for the group who prefers organic foods increases from 23.9 dollars to 26.1 dollars after providing the information, and the WTP for the group that does not prefer organic foods increases from 17.3 dollars to 19.3 dollars after providing the information. Therefore, due to the provision of the information, the WTP for the group that prefers organic foods rises by 2.2 dollars $(9.1 \%)$ and the WTP for the group that does not prefer organic foods rises by 2.0 dollars $(11.2 \%)$. In other words, the value of GM-use information is analyzed to be greater in the group who prefers organic foods.

These results in this study indicate that consumers who are more concerned about food safety have higher WTP for non-GM cooking oil, and are more sensitive to the information on the use of GM raw materials. Moreover, consumers with high prior knowledge of GMOs have higher WTP for non-GM cooking oil and are less sensitive to GM-use information(Table 4).

The result of analyzing the awareness of GMOs into four groups rather than two groups shows the effect of providing GM-use information more clearly as shown in Table 5. In the group with the lowest awareness of GMOs who responded "never heard", the change in WTP, which is the information value, is 3.6 dollars $(23.8 \%)$ and the difference is found to be the biggest. The change in WTP according to the information provided by the groups who responded "heard of it" and "knows little" are 2.6 dollars $(13.6 \%)$ and 1.7 dollars (7\%), respectively. The change in WTP according to the information provided by the group who responded "knows well" is 0.6 dollars (2.4\%), which is the smallest change in WTP due to the provision of the information. In other words, consumers with high prior knowledge of GMOs 
are aware that GM soybean is the most common ingredient of cooking oil on the market and show high WTP before providing the information with relatively little change in WTP, due to the provision of GM-use information. Consumers with low prior knowledge of GMOs often do not recognize that the raw material of cooking oil is GM soybeans, so the WTP for non-GM cooking oil is low before providing the information with a relatively large change in WTP due to the provision of the information. To sum up, the higher the prior knowledge, the less consumer values of GM-use information, and the lower the prior knowledge is, the greater the consumer values GM-use information. Therefore, the effect of the GMO labeling policy varies depending on the awareness of GMOs. The lower the awareness is, the greater the effect is anticipated, which is suggested by the significant difference between the WTP change across the groups with the highest and the lowest awareness, due to the information provided.

Table 4. Estimate Results of WTP using DBDC: WTP for Non-GM Cooking Oil. Unit: Dollars/1.8 L.

\begin{tabular}{|c|c|c|c|c|c|}
\hline \multicolumn{2}{|c|}{ Classification } & $\begin{array}{c}\text { Before } \\
\text { Providing } \\
\text { Information } \\
\text { (A) }\end{array}$ & $\begin{array}{c}\text { After } \\
\text { Providing } \\
\text { Information } \\
\text { (B) }\end{array}$ & $\begin{array}{c}\text { Change in } \\
\text { Amount (A-B) }\end{array}$ & $\begin{array}{c}\text { Change in } \\
\text { Rate }(\%)\end{array}$ \\
\hline \multicolumn{2}{|c|}{ Average } & $\begin{array}{l}21.1^{* * *} \\
(19.49)\end{array}$ & $\begin{array}{l}23.2 * * * \\
(21.67)\end{array}$ & 2.1 & 9.9 \\
\hline \multirow{2}{*}{$\begin{array}{l}\text { Preference for } \\
\text { organic food }\end{array}$} & $\begin{array}{l}\text { Group with } \\
\text { preference }\end{array}$ & $\begin{array}{l}23.9 * * * \\
(16.45)\end{array}$ & $\begin{array}{l}26.1^{* * *} \\
(17.96)\end{array}$ & 2.2 & 9.1 \\
\hline & $\begin{array}{l}\text { Group with no } \\
\text { preference }\end{array}$ & $\begin{array}{l}17.3^{* * *} \\
(9.94)\end{array}$ & $\begin{array}{l}19.3 * * * \\
(11.31)\end{array}$ & 2.0 & 11.2 \\
\hline \multirow{2}{*}{ Awareness of GMO } & $\begin{array}{c}\text { Group with } \\
\text { high awareness }\end{array}$ & $\begin{array}{l}23.8^{* * *} \\
(15.71)\end{array}$ & $\begin{array}{l}25.6^{* * *} \\
(17.06)\end{array}$ & 1.8 & 7.6 \\
\hline & $\begin{array}{l}\text { Group with low } \\
\text { awareness }\end{array}$ & $\begin{array}{l}18.0^{* * *} \\
(10.85)\end{array}$ & $\begin{array}{l}20.3^{* * *} \\
(12.46)\end{array}$ & 2.3 & 13.4 \\
\hline
\end{tabular}

Note: $t$-values are in parentheses, and ${ }^{* * *}, * *$, and ${ }^{*}$ denote significant at $1 \%, 5 \%$, and $10 \%$, respectively.

Table 5. Changes in WTP with Respect to Awareness: WTP for Non-GM Cooking Oil. Unit: US Dollars/1.8 L.

\begin{tabular}{cccccc}
\hline \multirow{2}{*}{ Classification } & $\begin{array}{c}\text { Before } \\
\text { Providing } \\
\text { Information } \\
\text { (A) }\end{array}$ & $\begin{array}{c}\text { After } \\
\text { Providing } \\
\text { Information } \\
\text { (B) }\end{array}$ & $\begin{array}{c}\text { Change in } \\
\text { Amount (A-B) }\end{array}$ & $\begin{array}{c}\text { Change in } \\
\text { Rate (\%) }\end{array}$ \\
\hline \multirow{2}{*}{ Average } & $\begin{array}{c}21.1^{* * *} \\
(19.52)\end{array}$ & $\begin{array}{c}23.2^{* * *} \\
(21.67)\end{array}$ & 2.1 & 10.0 \\
\cline { 2 - 6 } 1. Never heard & $\begin{array}{c}14.9^{* * *} \\
(6.17)\end{array}$ & $\begin{array}{c}18.5^{* * *} \\
(7.79)\end{array}$ & 3.6 & 23.8 \\
\cline { 2 - 6 } Awareness of GMO & 2. Heard of it & $\begin{array}{c}19.0^{* * *} \\
(14.59)\end{array}$ & $\begin{array}{c}21.6^{* * *} \\
(16.88)\end{array}$ & 2.6 & 13.6 \\
\cline { 2 - 6 } & 3. Knows little & $\begin{array}{c}23.1^{* * *} \\
(17.91)\end{array}$ & $\begin{array}{c}24.8^{* * *} \\
(19.26)\end{array}$ & 1.7 & 2.0 \\
\cline { 2 - 6 } & 4. Knows well & $\begin{array}{c}27.3^{* * *} \\
(11.36)\end{array}$ & $\begin{array}{c}27.9^{* * *} \\
(11.73)\end{array}$ & 0.6 & 2.4 \\
\hline
\end{tabular}

Note: $t$-values are in parentheses, and ${ }^{* * *}, * *$, and $*$ denote significant at $1 \%, 5 \%$, and $10 \%$, respectively.

\section{Conclusions}

In this study, we analyzed how consumers' willingness to pay changes when provided the objective information that most of the current cooking oil in the market uses GM materials. A hypothetical cooking oil product using non-GM raw materials was set up, and consumers were classified into high and low awareness groups for GMOs and those who prefer organic foods and those who do not, in order to compare the change in WTP. 
As a result of dividing consumers into two groups according to their prior knowledge about GMOs, the change in the amount of WTP due to the provision of GM-use information is analyzed to be 1.8 dollars for the group with high prior knowledge and 2.3 dollars for the group with low prior knowledge. As a result of dividing consumers into four groups according to their prior knowledge, the WTP changes due to the provision of GM-use information are estimated to be $0.6,1.7,2.6$, and 3.6 dollars for the groups with the highest to the lowest recognition level. In other words, the change in the amount of WTP turns out to be greater in the consumer group with low prior knowledge. This suggests that consumers with high prior knowledge of GMOs are aware that GM soybeans are the most commonly used ingredient for making cooking oil in the market, and are less sensitive to the provided GM-use information. Consumers with low prior knowledge, however, do not realize that the raw material of cooking oil is GM soybeans.

Considering the result of classifying consumers according to their prior knowledge about GMOs, Hypothesis 1 can be confirmed by the fact that the WTP of the consumer group with high prior knowledge also changes due to the provision of GM-use information, and Hypothesis 2 can be confirmed through the results of a larger change in the WTP for the consumer groups with low prior knowledge. In addition, the degree of change in WTP due to the provision of the information turns out to be larger in the group with low prior knowledge, however, the WTP for non-GM cooking oil after the provision of the information turns out to be higher in the group with high prior knowledge. This suggests that Hypothesis 3 is confirmed too.

From the empirical results for Hypothesis 1 and Hypothesis 2, we can see that when the GMO labeling policy is strengthened, there will be an increase in the preference for non-GM and its increase will be more noticeable in the group with low GM awareness. The result for hypothesis 3 suggests that the policy to raise prior interest in food safety and environmental impact is important, and, at the same time, providing information on GMOs would be an effective policy tool for activating the market of non-GM foods.

The results of this study are expected to be useful as the preliminary research for the analysis of economic impacts to determine whether to implement the mandatory complete GM food labeling system. However, since this study focuses on the expected change in WTP of non-GM foods by assuming the implementation of a mandatory full GM food labeling system, it has the limitation in estimating the realized change in WTP of GM foods. To determine whether to implement the mandatory full GM food labeling system, it is necessary to analyze the economic impacts by considering the WTP of labeled GM and non-GM foods at the same time. It must be determined by examining whether the two products will have completely differentiated markets or will exist in the same market where there is a difference in quality between the two products. The proposed limitations need to be reinvestigated with further studies in the future.

Author Contributions: K.N. designed the experiments and performed estimations and simulations; H.L. collected data and wrote the first draft of the paper; B.-i.A. organized the research and contributed analysis tools. All authors have read and agreed to the published version of the manuscript.

Funding: This research received no external funding.

Conflicts of Interest: The authors declare no conflict of interest. 


\section{Appendix A}

Table A1. Survey Before Providing GM-Use Information.

A. The price of cooking oil made from $100 \%$ non-GMO soybeans without any use of GMO soybeans is 8.9 dollars/1.8 L, would you buy it?

(1) Yes (go to Question A-1)

(2) No (go to Question A-2)

A-1. Then, if the price of cooking oil produced from $100 \% \quad$ A-2. Then, if the price of cooking oil produced from $100 \%$ non-GMO soybeans is 17.8 dollars $/ 1.8 \mathrm{~L}$ of the suggested non-GMO soybeans is 4.5 dollars $/ 1.8 \mathrm{~L}$ of the suggested price, would you buy it? (1) Yes (2) No price, would you buy it?

$$
\text { (1) Yes (2) No }
$$

\footnotetext{
Note: suggested price $1=8.9$ dollars (Ask $25 \%$ of respondents); suggested price $2=17.8$ dollars (Ask $25 \%$ of respondents); suggested price $3=26.8$ dollars (Ask $25 \%$ of respondents); suggested price $4=35.7$ dollars (Ask $25 \%$ of respondents).
}

Table A2. Survey after Providing GM-Use Information.

B. GMO soybeans are used in most of the cooking oils currently sold in the market, except for a few specific brands. If the price of cooking oil made from $100 \%$ non-GMO soybeans without any use of GMO soybeans is 8.9 dollars/1.8 L, would you buy it?

(2) Yes (go to Question B-1)

B-1. Then, if the price of cooking oil produced from $100 \%$ non-GMO soybeans is 17.8 dollars/1.8 $\mathrm{L}$ of the suggested price, would you buy it?

$$
\text { (1) Yes (2) No }
$$

(3) No (go to Question B-2)

B-2. Then, if the price of cooking oil produced from $100 \%$ non-GMO soybeans is 4.5 dollars/1.8 L of the suggested price, would you buy it? (1) Yes (2) No

\footnotetext{
Note: suggested price $1=8.9$ dollars (Ask $25 \%$ of respondents); suggested price $2=17.8$ dollars (Ask $25 \%$ of respondents); suggested price $3=26.8$ dollars (Ask 25\% of respondents); suggested price $4=35.7$ dollars (Ask $25 \%$ of respondents).
}

\section{Appendix B}

After providing GM-use information, the percentage of respondents responding "no-no" decreased from $22.8 \%$ to $18 \%$ and the percentage of respondents responding "yes-yes" increased from $12 \%$ to $14 \%$. 
Table A3. WTP for Non-GM Cooking Oil by the Amount Presented before and after Provision of GM-Use Information (DBDC)

\begin{tabular}{|c|c|c|c|c|c|c|c|c|c|c|c|}
\hline \multirow{3}{*}{$\begin{array}{l}\text { Providing } \\
\text { Information }\end{array}$} & \multirow{3}{*}{$\begin{array}{l}\text { Amount } \\
\text { Presented } \\
\text { (US Dollars) }\end{array}$} & \multicolumn{8}{|c|}{ Willingness to Pay Response Frequency } & \multirow{2}{*}{\multicolumn{2}{|c|}{ Total }} \\
\hline & & \multicolumn{2}{|c|}{ (No-No) } & \multicolumn{2}{|c|}{ (No-Yes) } & \multicolumn{2}{|c|}{ (Yes-No) } & \multicolumn{2}{|c|}{ (Yes-Yes) } & & \\
\hline & & $\begin{array}{l}\text { No. of } \\
\text { Respondents }\end{array}$ & $\begin{array}{c}\text { Ratio } \\
(\%)\end{array}$ & $\begin{array}{c}\text { No. of } \\
\text { Respondents }\end{array}$ & $\begin{array}{c}\text { Ratio } \\
(\%)\end{array}$ & $\begin{array}{c}\text { No. of } \\
\text { Respondents }\end{array}$ & $\begin{array}{c}\text { Ratio } \\
(\%)\end{array}$ & $\begin{array}{c}\text { No. of } \\
\text { Respondents }\end{array}$ & $\begin{array}{c}\text { Ratio } \\
(\%)\end{array}$ & $\begin{array}{c}\text { No. of } \\
\text { Respondents }\end{array}$ & $\begin{array}{c}\text { Ratio } \\
(\%)\end{array}$ \\
\hline Before & \multirow{2}{*}{8.9} & 6 & 10.0 & 8 & 13.3 & 27 & 45.0 & 19 & 31.7 & \multirow{2}{*}{60} & \multirow{2}{*}{100} \\
\hline After & & 3 & 5.0 & 9 & 15.0 & 26 & 43.3 & 22 & 36.7 & & \\
\hline Before & \multirow{2}{*}{17.8} & 11 & 20.0 & 17 & 30.9 & 23 & 41.8 & 4 & 7.3 & \multirow{2}{*}{55} & \multirow{2}{*}{100} \\
\hline After & & 7 & 12.7 & 18 & 32.7 & 25 & 45.5 & 5 & 9.1 & & \\
\hline Before & \multirow{2}{*}{26.8} & 23 & 31.5 & 27 & 37.0 & 20 & 27.4 & 3 & 4.1 & \multirow{2}{*}{73} & \multirow{2}{*}{100} \\
\hline After & & 18 & 24.7 & 27 & 37.0 & 24 & 32.9 & 4 & 5.5 & & \\
\hline Before & \multirow{2}{*}{35.7} & 17 & 27.4 & 27 & 43.6 & 14 & 22.6 & 4 & 6.5 & \multirow{2}{*}{62} & \multirow{2}{*}{100} \\
\hline After & & 17 & 27.4 & 25 & 40.3 & 16 & 25.8 & 4 & 6.5 & & \\
\hline \multicolumn{2}{|c|}{$\begin{array}{c}\text { Total (before providing } \\
\text { information) }\end{array}$} & 57 & 22.8 & 79 & 31.6 & 84 & 33.6 & 30 & 12.0 & \multirow[t]{2}{*}{250} & \multirow[t]{2}{*}{100} \\
\hline Total (after pro & ing information) & 45 & 18.0 & 79 & 31.6 & 91 & 36.4 & 35 & 14.0 & & \\
\hline
\end{tabular}




\section{Appendix C}

As a result of the probit model analysis including demographic characteristics, it is estimated that the estimated value $(\hat{\delta})$ for the presented price $(1 / \sigma)$ is negative before and after providing GM-use information and is statistically significant at a $1 \%$ significance level.

In the estimation results of the model before providing the information on the use of GM raw materials, the presented price, having a disease, monthly household food consumption expenditure, organic food preference, and GMO awareness show significant results. After the provision of GM-use information, it is estimated that the presence of disease, average monthly food consumption expenditure, organic food preference, and GMO awareness are estimated to be significant. Organic food preferences are divided into a preferred group (strongly prefer and prefer) and a non-preferred group (neutral, do not prefer, and strongly do not prefer). GMO awareness is divided into high awareness groups (knows well and little) and low awareness groups (heard of it and never heard).

Table A4. Estimation Results of SBDC (CVM) Probit Model: WTP for Non-GM Cooking Oil.

\begin{tabular}{|c|c|c|c|c|c|}
\hline \multirow{2}{*}{\multicolumn{2}{|c|}{ Variables $^{1}$}} & \multicolumn{2}{|c|}{ Before Providing Information } & \multicolumn{2}{|c|}{ After Providing Information } \\
\hline & & Coefficients & $t$-Value & Coefficients & $t$-Value \\
\hline \multicolumn{2}{|c|}{ Price presented } & $-0.511^{-4 * * *}$ & -5.87 & $-0.481^{-4 * * *}$ & -5.63 \\
\hline \multicolumn{2}{|c|}{ Gender } & -0.134 & -0.64 & -0.250 & -1.19 \\
\hline \multicolumn{2}{|c|}{ Age } & 0.177 & 1.64 & 0.073 & 0.69 \\
\hline \multicolumn{2}{|c|}{ Education } & 0.017 & 0.11 & 0.021 & 0.14 \\
\hline \multicolumn{2}{|c|}{ Marriage } & 0.162 & 0.56 & 0.168 & 0.58 \\
\hline \multicolumn{2}{|c|}{ Having children under 8} & 0.356 & 1.22 & 0.327 & 1.13 \\
\hline \multicolumn{2}{|c|}{ Having disease } & 0.271 * & 1.42 & $0.342 *$ & 1.78 \\
\hline \multicolumn{2}{|c|}{$\begin{array}{l}\text { Monthly average household } \\
\text { income }\end{array}$} & 0.000 & 0.07 & 0.000 & -0.04 \\
\hline \multicolumn{2}{|c|}{$\begin{array}{l}\text { Monthly average food } \\
\text { consumption expenditure }\end{array}$} & $0.002^{* * *}$ & 1.91 & $0.001^{* * *}$ & 1.21 \\
\hline \multicolumn{2}{|c|}{ Preference for organic food } & $0.483^{* * *}$ & 2.54 & $0.574^{* * *}$ & 3.04 \\
\hline \multicolumn{2}{|c|}{ Awareness of GMO } & $0.493^{* * *}$ & 2.55 & $0.328 *$ & 1.71 \\
\hline \multirow{6}{*}{$\begin{array}{l}\text { Occupation } \\
\text { (Dummy) }^{2}\end{array}$} & Housewife & -0.604 & -1.11 & -0.610 & -1.12 \\
\hline & Employee & -0.046 & -0.11 & -0.016 & -0.04 \\
\hline & $\begin{array}{l}\text { Professor and } \\
\text { researcher }\end{array}$ & -0.061 & -0.08 & -0.118 & -0.16 \\
\hline & $\begin{array}{c}\text { Government } \\
\text { official }\end{array}$ & -0.240 & -0.45 & 0.172 & 0.32 \\
\hline & Self-employed & -0.157 & -0.32 & 0.041 & 0.08 \\
\hline & Others & -0.468 & -0.86 & -0.209 & -0.38 \\
\hline \multicolumn{2}{|c|}{ Constant } & -0.285 & -0.43 & 0.268 & 0.40 \\
\hline \multicolumn{2}{|c|}{ Pseudo $R^{2}$} & \multicolumn{2}{|c|}{0.202} & \multicolumn{2}{|c|}{0.196} \\
\hline \multicolumn{2}{|c|}{ Log likelihood } & \multicolumn{2}{|c|}{$-137,442$} & \multicolumn{2}{|c|}{$-139,278$} \\
\hline \multicolumn{2}{|c|}{$\chi^{2}(17)$} & \multicolumn{2}{|c|}{60,750} & \multicolumn{2}{|c|}{68,000} \\
\hline \multicolumn{2}{|c|}{ prob $>\chi^{2}$} & \multicolumn{2}{|c|}{0.000} & \multicolumn{2}{|c|}{0.000} \\
\hline
\end{tabular}

Note: ${ }^{* * *},{ }^{* *}$ and ${ }^{*}$ denote significant at $1 \%, 5 \%$, and $10 \%$, respectively. ${ }^{1}$ While the amount presented, age, education, monthly average household income, and food consumption expenditure are continuous variables, the remaining variables are dummy ( 0 or 1 ) variables. ${ }^{2}$ The reference variable for the occupation dummy variable is the student. 


\section{References}

1. Gilbert, N. A hard look at GM crops. Nature 2013, 497, 24-26. [CrossRef] [PubMed]

2. Fernandez-Cornejo, J.; Wechsler, S.; Livingston, M.; Mitchell, L. Genetically Engineered Crops in the United States; Economic Research Report, ERR-162; USDA: Washington, DC, USA, 2014.

3. Andreasen, M. GM food in the public mind-facts are not what they used to be. Nat. Biotechnol. 2014, $32,25$. [PubMed]

4. Klumper, M.; Qaim, M. A Meta-Analysis of the Impacts of Genetically Modified Crops. PLoS ONE 2014, 9, e111629. [CrossRef] [PubMed]

5. Zilberman, D.; Holland, T.G.; Trilnick, I. Agricultural GMOs-What We Know and Where Scientists Disagree. Sustainability 2018, 10, 1514. [CrossRef]

6. Brookes, G.; Barfoot, P. Environmental impacts of genetically modified (GM) crop use 1996-2018: Impacts on pesticide use and carbon emissions. GM Crops Food 2015, 6, 103-133. [CrossRef] [PubMed]

7. DeFrancesco, L. How safe does transgenic food need to be? Nat. Biotechnol. 2013, 31, 794-802. [CrossRef] [PubMed]

8. Pray, C.E.; Huang, J.; Hu, R.; Rozelle, S. Five years of Bt cotton in China-The benefits continue. Plant J. 2002, 31, 423-430. [CrossRef] [PubMed]

9. Huang, J.; Hu, R.; Rozelle, S.; Pray, C. Genetically modified rice, yields and pesticides: Assessing farm-level productivity effects in China. Econ. Dev. Cult. Chang. 2008, 56, 241-263.

10. Ali, A.; Abdulai, A. The adoption of genetically modified cotton and poverty reduction in Pakistan. J. Agric. Econ. 2010, 61, 175-192. [CrossRef]

11. Kathage, J.; Qaim, M. Economic impacts and impact dynamics of Bt (Bacillus thuringiensis) cotton in India. Proc. Natl. Acad. Sci. USA 2012, 109, 11652-11656. [CrossRef] [PubMed]

12. Stone, G.D. Constructing facts: Bt cotton narratives in India. Econ. Political Wkly. 2012, 47, 62-70.

13. Glover, D. Is Bt cotton a pro-poor technology? A review and critique of the empirical record. J. Agrar. Chang. 2010, 10, 482-509. [CrossRef]

14. Lee, S.H. Labeling system for genetically modified foods by major countries. In World Agriculture; Korea Rural Economic Institute (KREI): Naju, Korea, 2017; Volume 207.

15. Hwang, Y.J.; Han, J.H.; Lee, K.I. An Anlaysis of Cosumers' Perception on Developing and Cultivating GM Agricultural Products. Korean J. Agric. Manag. Policy 2015, 42, 1-18.

16. Delmond, A.R.; McCluskey, J.J.; Yormirzoev, M.; Rogova, M.A. Russian consumer willingness to pay for genetically modified food. Food Policy 2018, 78, 91-100. [CrossRef]

17. Zhu, X.; Xie, X. Effects of Knowledge on Attitude Formation and Change Toward Genetically Modified Foods. Risk Anal. 2015, 35, 790-810. [PubMed]

18. Han, J.H.U.S. Consumers' Estimation for Mandatory Labeling Policy toward GM Foods. J. Consum. Stud. 2009, 20, 3.

19. Kim, H.S.; Kim, K.S. A multi-country assessment of consumer's acceptance and willingness to pay for genetically modified foods and the implication new labeling system. Korean J. Agric. Manag. Policy 2005, 32, 171-186.

20. Ahn, B.I.; Choi, J.H.; Lee, B.H.; Nam, K.S.; Lim, H.S. Impact of the GMO Labeling System on the Food Industry; Research paper; Korea Agricultural Economics Association: Seoul, Korea, 2018; p. 164.

21. Korea Agro-Fisheries and Food Trade Corporation. Survey on Raw Material Consumption in Each Food Industry; Korea Agro-Fisheries and Food Trade Corporation: Naju, Korea, 2017.

22. Lopez-Feldman, A. Introduction to Contingent Valuatio Using Stata; MPRA: Munich, Germany, 2012.

23. Hanemann, M.; Loomis, J.; Kaninnen, B. Statistical Efficiency of Double-Bounded Dichotomous Choice Contingent Valuation. Am. J. Agric. Econ. 1991, 73, 1255-1263.

24. Portney, P.R. The Contingent Valuation Debate: Why Economists Should Care. J. Econ. Perspect. 1994, 8, 3-17. [CrossRef]

(C) 2020 by the authors. Licensee MDPI, Basel, Switzerland. This article is an open access article distributed under the terms and conditions of the Creative Commons Attribution (CC BY) license (http://creativecommons.org/licenses/by/4.0/). 